\title{
Family Firms And Corporate Social Responsibility (CSR): Preliminary Evidence From The French Stock Market
}

Issam Laguir, Groupe Sup de Co Montpellier Business School, France Jamal Elbaz, Ibn Zohr University, Morocco

\begin{abstract}
This paper examines the CSR practices of family firms listed in the French financial market and distinguishes between those managed by a family member CEO and those managed by a competent external CEO. We adopt an exploratory approach and begin with a content analysis of the annual reports from family firms listed in the CAC 40 index during the 2005-2011 period. We then conduct various statistical techniques (e.g., Pearson correlation analysis and ordinary least squares regression analysis) to study the relationships among social performance and family involvement.

This paper is the first to provide a preliminary assessment of French family firms' CSR practices in the current economic context. The study suggests that family firms intensify their CSR efforts during the 2005-2011 period. Our study also reveals that family firms managed by competent external CEOs show better social performance than those managed by family member CEOs. Indeed, the empirical results consistently show a negative and statistically significant association between family involvement and corporate social performance.
\end{abstract}

Keywords: Corporate Social Responsibility (CSR); Family Firms; Performance; Family Involvement

\section{INTRODUCTION}

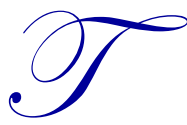

he concept of corporate social responsibility (CSR) has taken on increasing interest for both firms and their stakeholders. The latter continue to focus on the potential impact of company business in the economic, social, and environmental spheres, thereby pushing companies to redefine their responsibilities toward society, establish actions to protect the environment and combat exclusion, and/or participate in the local economy. Indeed, stakeholders are those with rights to the account and it is for them that the account is prepared (Gray et al., 1997). From this perspective, CSR can be considered as a company's response to social and environmental issues through strategies and methods of control, monitoring, evaluation, and reporting that incorporate new approaches to performance (Capron \& Quairel-Lanoizelée, 2007).

With regard to family-owned businesses, several studies have examined the impact of family involvement on the development of CSR practices. These studies have found that the more the family is present in company management, the greater the effort to develop CSR (Aronoff \& Ward, 1995; Chrisman et al., 2005; O'Boyle et al., 2010). However, no study to our knowledge has focused on the commitment of French family businesses to CSR according to governance mode.

This paper provides an initial assessment of CSR practices in family-owned companies in the current economic crisis and with respect to the degree of family involvement in firm governance. We briefly review the concept of CSR and then analyze the impact of family involvement on CSR practices from a performance perspective. Our research hypotheses are presented in the second section. The methodology and the empirical results of our work are detailed in the third and fourth sections. We then finish our study with a discussion and a general conclusion. 


\section{THEORETICAL FRAMEWORK}

\subsection{Corporate Social Responsibility (CSR)}

Despite several important contributions to the literature in recent decades, there is still no consensual definition of CSR (Matten \& Moon, 2008; Wan, 2006; van Marrewijk, 2003).

Bowen (1953) initially introduced the concept of CSR in business management, arguing that companies have a moral duty to act in a socially responsible way toward society and future generations (Capron \& QuairelLanoizelée, 2004). Subsequently, Carrol (1979) defined CSR as a set of obligations toward society: economic (to maximize profit, to create value, and quality products), legal (to respect the laws and regulations), ethical (to act according to moral principles shared within the company), and philanthropic (to be charitable).

In the 1980s, CSR underwent further transformations, and the notion of stakeholders proposed by Freeman (1984) became central to implementing CSR within companies. A stakeholder can be defined as "an individual or group that may affect the fulfillment of the objectives of an organization or who is affected by the achievement of the objectives of an organization" (Freeman, 1984). For Carroll (1991), stakeholders are the owners, customers, employees, the community to which a company belongs, its competitors, suppliers, activist groups, society in general, and any group or person affected by the company's activities. Thus, a socially responsible company is one which takes its stakeholders into account when it comes to making decisions. Wood (1991) enhanced Carroll's approach (1979) by distinguishing three levels of corporate social responsibility: responsibility at the institutional level, the activity level, and the individual level.

The role of regulators is at the heart of CSR concerns. For example, in 2001, the European Community Commission defined CSR as "the voluntary integration by companies of social and environmental concerns in their business operations and their relationships with their stakeholders. The main function of an enterprise is to create value, (...) for its owners and shareholders, while contributing to the welfare of society." French regulators, for their part, have expressed CSR concerns through various measures. The first one was the 2001 NRE law requiring listed companies to publish information on how they deal with the social and environmental consequences of their activity. The second was the 2005 environmental charter, which emphasized the rights of all citizens to live in a healthy and balanced environment and participate in the development of public decisions that affect the environment. The third measure was the "Grenelle 1" law followed by "Grenelle 2," which standardized the social and environmental indicators by industry, prepared the way for modules on the environment, sustainable development, and risk prevention to be integrated into company training plans, and set the course for establishing forums for stakeholder dialogue in the social sphere.

\subsection{Family Involvement and CSR}

The notion of family business involvement has no single definition. Some define it as the family's share (degree of ownership) in the capital of the company (Anderson \& Reeb, 2003), while others define it with respect to the family members working in the company (Mishra \& McConaughy, 1999). In our paper, we adopt the definition of Chua et al. (1999) and consider family involvement to mean substantial family presence in ownership, governance, management, succession, and/or employment. Several studies have focused on the analysis of family involvement in CSR and have shown that family businesses (or those with a high degree of family involvement) display a clear CSR orientation in their activities (Aronoff \& Ward, 1995; Dyer \& Whetten, 2006; Miller \& Le Breton-Miller, 2003). There are several legitimate and competing theories as to why firms in general, and family businesses in particular, are likely to be socially responsible.

From the stakeholder-oriented perspective, Freeman (1984) argued that, although a corporation exists primarily to make money for its shareholders, it must also satisfy the needs of its other stakeholders. Freeman was the first scholar to clearly identify the strategic importance of groups and individuals beyond the firm's stockholders; he pointed to such widely disparate groups as local community organizations, environmentalists, consumer advocates, governments, special interest groups, and even competitors and the media as legitimate stakeholders. These stakeholders can withdraw resources destined for the company and thereby endanger its 
existence. They therefore need to be managed to ensure their continued support and to ultimately ensure that corporate objectives are met (Mitchell et al., 1997; Roberts, 1992).

Compared with stakeholder theory, legitimacy theory appears to be less tied to the assumption of discrete and identifiable factions of stakeholders. According to Suchman (1995), legitimacy is a state in which an organization's actions are seen to be “...desirable, proper or appropriate within some socially constructed system of norms, values, beliefs and definitions" (1995, p. 574). Legitimacy theory assumes that an organization is in part defined by its ability to engage in and control the processes of legitimation to demonstrate its congruence with societal values (Magness, 2006). Indeed, given a growth in community awareness and concern, a firm is expected to take measures to ensure that its activities and performance are acceptable to the community (Wilmshurst \& Frost, 2000). Moreover, legitimacy can be seen as an operational resource (Suchman, 1995; Tilling \& Tilt, 2010) whose value must be maintained to ensure continued support from society. The latter is expressed, for example, in terms of increased capital inflows, customer and supplier appreciation, labor participation, government "blessing," and community (and media) acceptance when the company acts as a good and environmentally friendly "corporate citizen." However, should there be a perceived mismatch between organizational activities and societal values, a legitimacy gap will develop (Haniffa \& Cooke, 2005) and may threaten the organization's status within the broader social system.

According to stewardship theory, managers identify with their organization and do not instinctively act in opportunistic ways (Davis et al., 1997). Interestingly, successful family businesses often operate on the basis of a stewardship philosophy (Corbetta \& Salvato, 2004). Stewardship theory depicts organizational members as collectivists, pro-organizational, and trustworthy (Davis et al., 1997). In the realm of stewardship, managers are more concerned about the well-being of the organization and find their identity tied to that of the organization. If the organization has a favorable reputation with internal and external stakeholders, then managers may receive both intrinsic and extrinsic rewards, which prompt them to increase the organization's performance while concurrently maximizing their own utility through their identification with the organization (Dibrell \& Moeller, 2011). In sum, stewardship behaviors refer to actions signifying a collectivist orientation toward an organization's well-being. Stewardship therefore also includes the extent to which individuals express their loyalty/commitment to an organization, which may be a direct result of the wages and/or level of professionalism practiced within the organizational premises (Zahra et al., 2008).

Social identity theory posits that individuals view themselves as extensions of the groups in which they hold memberships, particularly, those groups with which a person is closely identified (Hogg, 2003; Hogg \& Terry, 2001). To avoid negative self-views, members who closely identify with a group that develops a bad reputation will, other things being equal, switch to groups with better reputations. The obvious problem that the owners of family businesses face is that, in response to bad publicity, they cannot, practically speaking, switch groups; they therefore tend to band together to preserve the family's reputation (Dyer \& Whetten, 2006).

From this stream of theory, if a family firm is motivated to create positive moral capital or has a "socially responsible identity," the firm should be proactive in launching CSR actions consistent with its identity or in attempting to create goodwill. Under these conditions we should find:

Hypothesis 1: Family firms managed by family member CEOs will present better social performance than those managed by competent external CEOs.

From a self-interest perspective, the dynamic of amoral familism suggests that owning-families would be more likely to emphasize self-interest than to be socially responsible. Moreover, family firms are breeding grounds for relationships fraught with conflict (Dyer, 1986; Kaye, 1991; Lansberg, 1999; Ward, 1987), as family members may have competing goals and values that spring from complex conflicts and family dynamics arising from the family's psychosocial history (Hilburt-Davis \& Dyer, 2003). Schulze et al. (2003) argue that the dispersion of ownership in family-held firms also drives a wedge between the interests of those who lead a firm, and often own a controlling interest, and other family owners. The outcomes might be behaviors such as nepotism, which could disadvantage company employees and other stakeholders, or competing in the marketplace in ways that could prove harmful to the greater social good (Rosenblatt et al., 1985; Schulze et al., 2001). Last, case studies have 
demonstrated how certain families employ amoral familism in their relationships with their employees (Christensen, 2002). Nonfamily employees are treated as "second-class citizens" and are exploited by the family. Such an adversarial relationship between an owning-family and nonfamily employees often results in low employee morale and low productivity.

Morck and Yeung (2004) go so far as to argue that family firms are highly self-interested and merely want to protect their own parochial interests. Thus, the families that own various enterprises would not be inclined to improve the broader societies in which their firms are embedded. Such family firms may even foster corruption, which undermines public confidence as well as the legitimacy of public institutions, in order to protect their own interests. These authors (2004) further emphasize that professional managers with brief careers might be socially preferable to enduring family control over large corporations because this discourages repeated games of political rent-seeking. Gomez-Mejia et al. (2001) report that the Spanish family firms they studied were much more reluctant to fire a family CEO than were nonfamily firms, but when the family CEO was replaced, the firm performed significantly better after the transition than those nonfamily firms that also replaced their CEOs. The implication is that family owners, as a result of altruism, are unwilling to monitor and discipline their CEOs; hence the family CEOs became entrenched. Only establishing the correct balance between operational pressures and counter-opinions can ensure that family firms make the best choices when faced with strategic decisions. Once this has been achieved, the dichotomy between family members and managers must make room for a new type of corporate governance in which an alliance between both has proved to be particularly efficient (Le Foll \& Pirey, 2004). From this perspective, the CEO is called to play a crucial role and the competent external CEO is expected to be more able to ensure better corporate social effort than a family member CEO could do.

In summary, if self-interest theory is correct that family firms act in self-interested ways to the detriment of society, we should find:

Hypothesis 2: Family firms managed by competent external CEOs will present better social performance than those managed by family member CEOs.

\section{METHODOLOGY}

The present paper identifies the CSR practices of French family firms with respect to the degree of family involvement. Specifically, we study the family firms listed in the CAC 40 financial market: Louis Vuitton (LVMH), Compagnie Générale des Etablissements Michelin, Cap Gemini, Alstom, Peugeot SA, Bouygues, PPR, Publicis Groupe SA, and Pernod Ricard. These firms are divided into two categories, depending on the degree of family involvement in their governance. Thus, we distinguish:

- Companies that have the family as the largest shareholder and a member of the family as CEO: LVMH, Peugeot SA, Cap Gemini, Bouygues, PPR, and Pernod Ricard. We refer to this group as Category A.

- Companies that have the family as the largest shareholder and a competent external CEO: L'Oréal, Compagnie Générale des Etablissements Michelin, Alstom, and Publicis Groupe SA. We refer to this group as Category B.

We empirically test our hypotheses based on publicly listed French family corporations collected from the DIANE financial database for the 2005 to 2011 financial years, which represents the latest and most complete financial years available for data collection. Our initial sample consisted of a sum total of 70 observations. However, the initial sample was reduced by the exclusion of 2 observations with missing financial data. Therefore, the final sample for our empirical analysis is comprised of 68 observations.

\subsection{Dependent Variable}

Specialized rating agencies generally assess CSR. However, they use a rather generic approach and it's often not clear how they conduct their assessments and arrive at their conclusions. The dependent variable for our study is denoted by CSR. Thus, to determine the CSR of our family firms, we assess their practices with respect to environmental, social, and governance (ESG) concerns. Our approach draws on the work of Sholtens (2009) and 
Maignan and Ralston (2002). Our measurement scale consists of five groups of indicators: ethics and sustainability (group 1), environmental management (group 2), responsible products (group 3), social conduct (group 4), and governance (group 5). Our major assumption is that firms demonstrate their commitment to social responsibility by adopting codes and developing and publishing CSR reports. In addition, the interest that firms show for the natural environment can be determined from environmental policies and/or supply chain management. Transparency about environmental performance and the management of environmental risks allow us to identify how a firm manages its environmental "footprint." The company commitment to CSR is also reflected through the creation and development of responsible products. These products benefit from eco-design processes that reduce the weight and volume of packaging, make use of appropriate components and raw materials, and ensure production based on energy efficiency and minimal carbon dioxide emissions. Social conduct refers to the assessment of a firm's internal and external social commitment: internal through its relationship with employees and external through its community involvement, volunteering, sponsoring, etc. Last, governance allows us to assess how the firm operates in this respect to reach CSR goals. Here we assess, for example, leadership commitment to CSR and stakeholder involvement in corporate governance.

It should be noted that our use of binary encoding ( 0 or 1$)$ for the CSR scores could be seen as a limitation of our study. Indeed, there is a potential argument for attaching weights to each CSR activity item because some items might be considered to be more important or have greater information value to the public than other items (see, e.g., Wallace, 1988). However, counter-arguments have also been raised for not using weights. Thus, Lanis and Richardson (2012) state that: (1) attaching weights to each CSR activity item assumes that certain items are more important than others, which could be a subjective assessment and may not necessarily be the case; and (2) within a large sample of CSR activity items, the different weights for CSR activity items could average or even-out. Moreover, empirical evidence based on research by Adhikari and Tondkar (1992) and Arzeski (1996), for example, indicates that there is little need to attach weights to CSR activity items. Therefore, we decided not to attach weights to any of the 25 individual CSR activity items in study.

Our main source of information is the documentation provided by the family firms, and we studied the CSR reports published from 2005 to 2011. When a firm did not provide a CSR report, we used the activity report and/or annual report to score CSR. These scores are derived by calculating the number of indicators forming each group. For example, if we have six indicators for "social conduct" and a company shows a positive score for three of them, the company is assigned a score of $50 \%$ for "social conduct." Appendix A summarizes the indictors used to identify the CSR practices of French family firms.

\subsection{Independent Variable}

Our independent variable is denoted by the dummy variable governance (GOV), which takes a value of 1 when the family firm is managed by a family member CEO and 0 otherwise.

\subsection{Control Variables}

We include several control variables from the CSR literature in our OLS regression model to control for other effects. They include corporation size, activity sector, and return on assets. Data for these control variables were collected from the DIANE financial database. For corporation size (SIZE), previous research (see, e.g., Stanwick \& Stanwick, 1998; Johnson \& Greening, 1999) shows that it is positively associated corporate social performance. Specifically, due to their higher visibility, larger corporations are likely to provide more extensive corporate social performance information in the annual report than smaller corporations (Cho et al., 2010). We measure SIZE as the natural log of total assets.

We include activity sector (SECT) in our study as a control variable given that previous research (see, e.g., Stray \& Ballantine, 2000; Cormier et al., 2004) shows that the activity sector makes a corporation much more visible to the public and to the community at large. Thus, firms belonging to sectors sensitive to the environment (energy, chemicals, mining, and construction) provide more corporate social performance information than others. We measure SECT as a dummy variable that takes the value 1 when the family firm's activity sector is sensitive to the environment and 0 otherwise. 
Finally, for return on assets (ROA), recent literature reviews have found a rather positive relationship between social performance and financial performance. This is particularly the case of the work of Margolis and Walsh (2003) on 127 empirical studies for the period 1972-2002. Of the 127 studies, 109 analyzed the link between social performance and financial performance. According to this meta-analysis, 54 studies (50\%) resulted in a positive link, 7 studies found a negative relationship, 28 studies reported a non-significant relationship, and 20 studies found a mixed relationship. These results are confirmed by the work of Orlitzky et al. (2003) with a metaanalysis of 52 empirical studies. We measure ROA as pre-tax income divided by total assets.

\subsection{Regression Model}

To test our hypotheses, we estimated the following OLS regression model:

$\mathrm{CSR}=\beta_{0}+\beta 1 \mathrm{GOV}+\beta_{2} \mathrm{SIZE}+\beta_{3} \mathrm{SECT}+\beta_{4} \mathrm{ROA}+\varepsilon$

where: CSR = the family firm's social performance estimated by the total score of the indicators listed in Appendix $\mathrm{A} ; \mathrm{GOV}=$ a dummy variable that takes the value 1 when the family firm is managed by a family member CEO and 0 otherwise; SIZE $=$ the firm size measured by the natural logarithm of total assets; SECT $=$ a dummy variable that takes the value 1 when the family firm's activity sector is sensitive to the environment (energy, chemicals, mining, and construction) and 0 otherwise; ROA = return on assets measured as pre-tax income divided by total assets; and $\varepsilon:$ the error term.

\section{RESULTS}

\subsection{Social Performance and Family Firms}

Appendix B presents the CSR scores for the French family firms during the 2005-2011 period. It shows that, in 2011, all family firms published a separate CSR report and were signatories of the Global Compact, while in 2005, only two companies in Category B published a separate CSR report and only one in Category A. In addition, in 2005, two companies in Category B and one in Category A were not members of the Global Compact. That year, no company was a signatory of the ICC Business Charter for Sustainable Development.

In 2011, all family firms had a certified environmental management system. All firms provided an explicit environmental policy, had a sustainable supply chain policy, provided quantitative measures of environmental performance, and had a policy for environmental risk management and an account for environmental risk. In contrast, in 2005, four companies in Category A and one company in Category B had no quantifiable objectives for environmental management. The firm in Category B also had no transparent environmental performance.

Concerning responsible products, all companies used eco-design processes and made efforts to improve customer awareness about "sustainable" approaches. In contrast, no company seemed interested in partnering with competing or complementary companies to create a CSR market. Furthermore, in 2005, only one company in Category B did not exclude toxic components, as opposed to four companies in Category A. In 2011, three of these firms still had no product component policy.

Concerning social conduct, all firms were active with respect to sponsoring local communities and NGOs and could be characterized by their community involvement. All firms offered training and education facilities and had diversity and equal opportunity policies for their employees. All had a code of ethical conduct and maintained dialogue with their employees in 2011, although one firm in Category A had no dialogue with its employees in 2005.

Concerning governance, the top managers of all firms expressed a commitment to CSR. All firms assessed their improvement in CSR actions, conducted internal evaluations of CSR policies, and involved stakeholders in their governance. In 2005, three companies in Category A had no external evaluation of their CSR policy, whereas all of them had these evaluations in 2011. 
Figures 1 and 2 indicate that family firms managed by a competent external manager had better social performance than those managed by a family member CEO, with a score of $92 \%$ for 2011 for all firms in Category $\mathrm{B}$, while only three companies in Category A had a similar score. This finding is more significant for the 2005 CSR scores. The highest score in Category A was $84 \%$ and concerned a single company, while it was $88 \%$ for $50 \%$ of the companies in Category B.

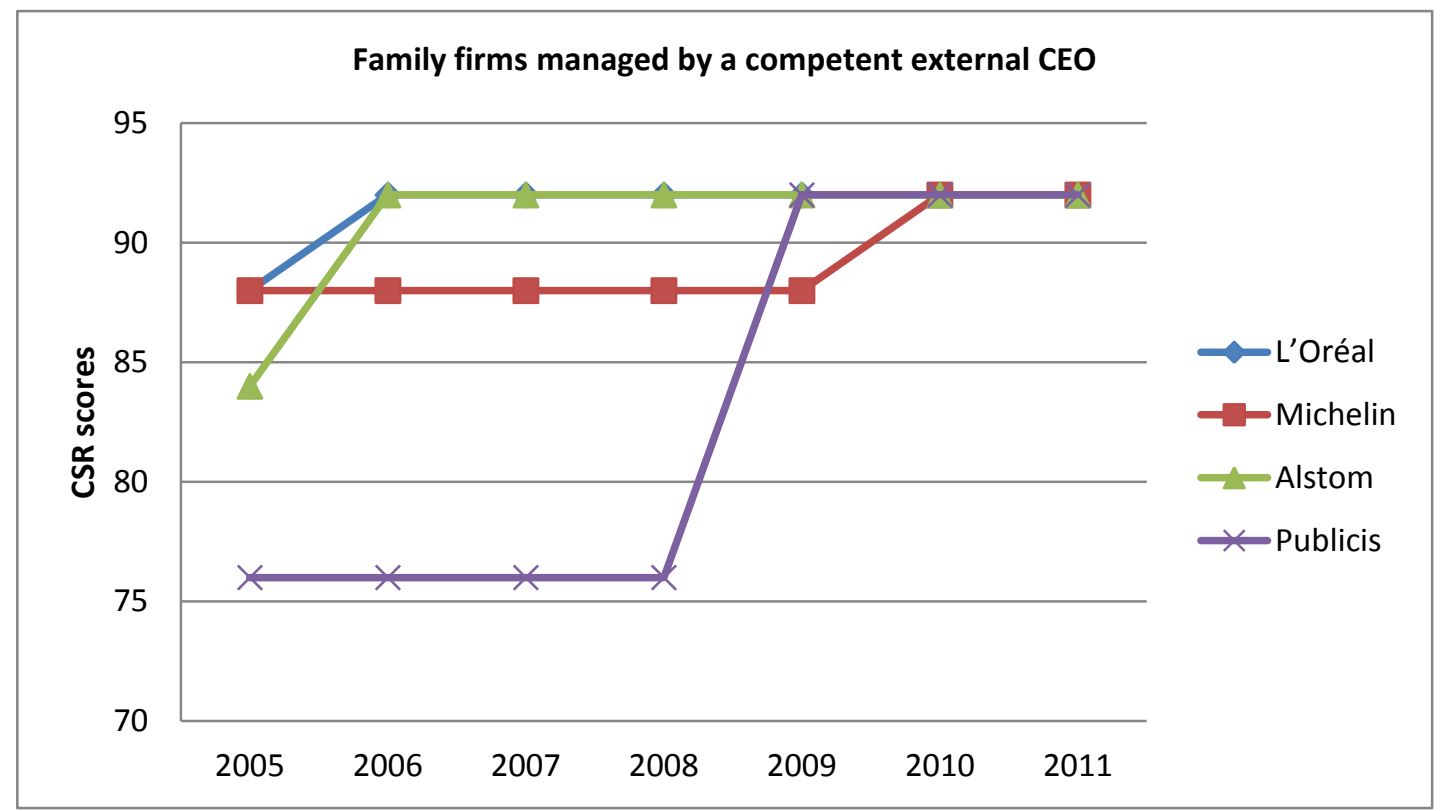

Figure 1: Family Firms Managed by a Competent External CEO

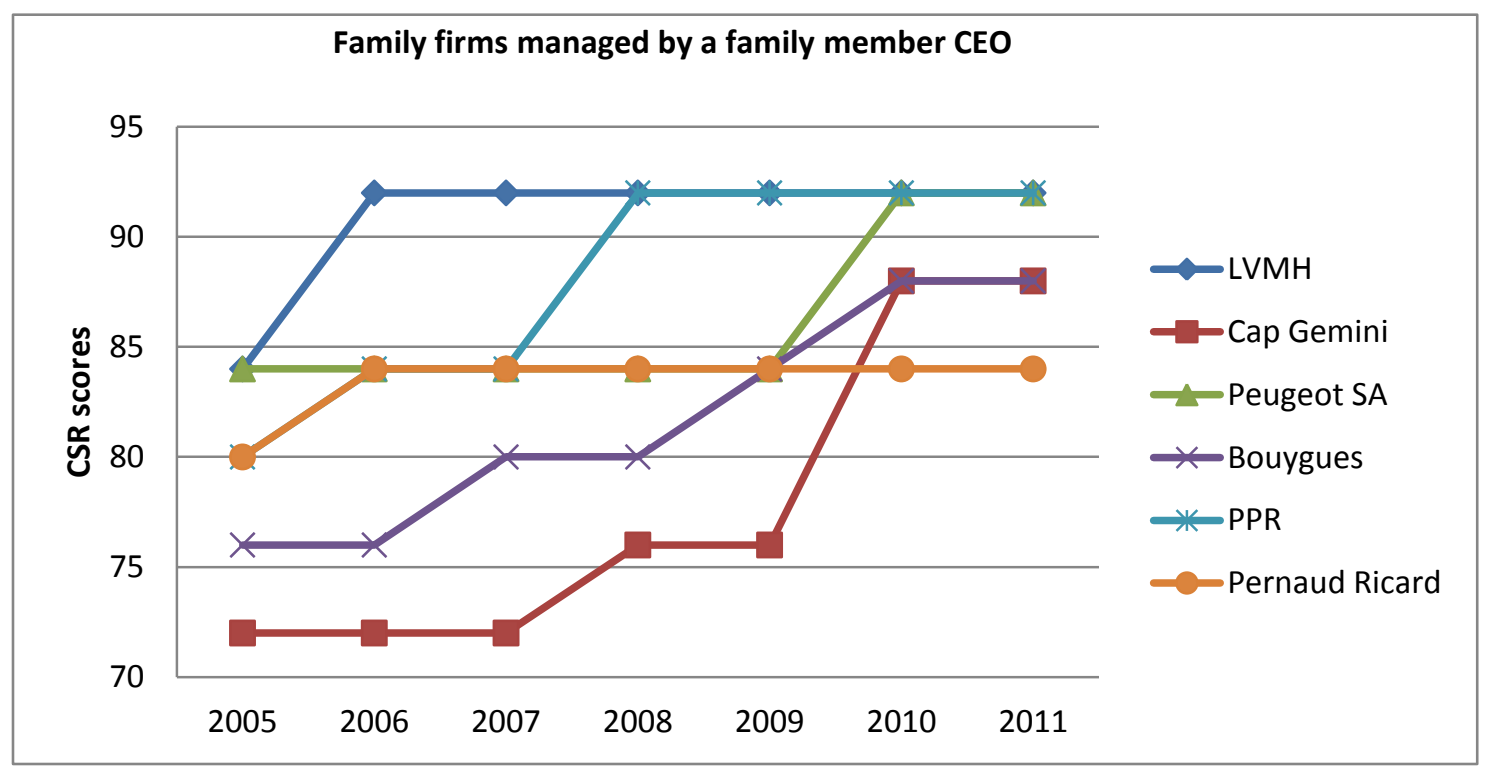

Figure 2: Family Firms Managed by a Family Member CEO

\subsection{Descriptive Statistics}

The descriptive statistics of our variables are reported in Table 1. The CSR levels of the corporations in our sample are relatively high with mean (median) of 86,176 (88). 
Table 1: Descriptive Statistics

\begin{tabular}{|c|c|c|c|c|c|c|}
\hline Variable & $\mathbf{N}$ & Mean & Std. dev. & Minimum & Median & Maximum \\
\hline Continuous Variables & & & & & & \\
\hline CSR & 68 & 86,176 & 6,312 & 72 & 88 & 92 \\
\hline SIZE & 68 & 7,008 & 0,154 & 6,320 & 7,045 & 7,260 \\
\hline ROA & 68 & 6,147 & 7,931 & $-0,850$ & 3,890 & 56,79 \\
\hline \multicolumn{7}{|l|}{ Dummy Variables } \\
\hline & & $0(\%)$ & $1(\%)$ & & & \\
\hline GOV & 68 & $27(39,7 \%)$ & $41(60,3 \%)$ & & & \\
\hline SECT & 68 & $42(61,8 \%)$ & $26(38,2 \%)$ & & & \\
\hline
\end{tabular}

Variable definitions: CSR $=$ social performance index between $0 \%$ and $100 \%$; SIZE $=$ the natural logarithm of total assets; ROA $=$ pre-tax income divided by total assets; GOV = a dummy variable that takes the value 1 when the family firm is managed by a family member CEO and 0 otherwise; SECT = a dummy variable that takes the value 1 when the family firm's activity sector is sensitive to the environment (energy, chemicals, mining, and construction) and 0 otherwise.

Table 1 also reports the descriptive statistics of the other continuous variables in our base regression model. SIZE has a mean (median) of 7,008 $(7,045)$ and ROA has a mean (median) of $6,147(3,890)$.

For the dummy variables, we report that for GOV, the slight majority of our sample (60\%) comprises of corporations that are managed by a family member CEO. However, for SECT we find that a slight majority of the sample (61\%) represents corporations belonging to activity sector non sensitive to the environment.

Overall, an acceptable range of variation is observed for all of the variables presented in Table 1 as well as a reasonable level of consistency between the means and medians, reflecting normality of distributions (see, e.g., Hair et al., 2006).

\subsection{Correlation Results}

The Pearson pairwise correlation results are presented in Table 2. The correlations show that CSR is significantly negatively associated with GOV $(\mathrm{p}<.001)$. These results indicate that the higher the corporation's level of family involvement, the lower is the level of corporate social performance, therefore providing some additional support for $\mathrm{H}_{2}$. We also find significant positive correlation between CSR and SIZE. As expected, larger corporations provide more corporate social smaller corporations.

Table 2: Pearson Correlation Results

\begin{tabular}{l|ccccc}
\hline \multicolumn{1}{c|}{ Variable } & CSR & GOV & SIZE & SECT & \\
\hline CSR & 1 & & & & \\
GOV &,$- 313^{* * *}$ & 1 & 1 & & \\
SIZE &, $321^{* * *}$ &, $236^{*}$ &, 063 & 1 &, 047 \\
SECT &, 447 &,- 166 &, 064 & 1 \\
ROA &, 144 &,$- 256^{* *}$ & & 1 \\
\hline
\end{tabular}

Variable definitions: CSR $=$ social performance index between $0 \%$ and $100 \%$; SIZE $=$ the natural logarithm of total assets; ROA $=$ pre-tax income divided by total assets; GOV = a dummy variable that takes the value 1 when the family firm is managed by a family member CEO and 0 otherwise; SECT = a dummy variable that takes the value 1 when the family firm's activity sector is sensitive to the environment (energy, chemicals, mining, and construction) and 0 otherwise. $\mathrm{N}=68$ for all variables. * Significance at the .10 level; ** Significance at the .05 level; *** Significance at the .01 level.

Table 2 also reports the correlations between the explanatory variables. It shows that only moderate levels of collinearity exist between the explanatory variables used in our study. The highest correlation coefficient is between GOV and ROA of $-0,256$ ( $\mathrm{p}$. .005). Moreover, we also calculate variance inflation factors (VIFs) when estimating our base regression model to test for signs of multi-collinearity among the explanatory variables. Our results reported in Table 3 confirm that no VIFs exceed five for any of our explanatory variables, so multicollinearity is not problematic in our base regression model. 


\subsection{Regression Results}

The OLS regression results used to test our hypotheses are reported in Table 3 . The regression coefficient for GOV is negative and significant ( $<<0,01$ ), which provides further support for $\mathrm{H}_{2}$ and is consistent with selfinterest theory.

Table 3: OLS Regression Results

\begin{tabular}{l|ccccc}
\hline \multicolumn{1}{c|}{ Variable } & Predicted Sign & Coefficient & Standard Error & t-statistic & VIF \\
\hline Intercept & $?$ & $-30,112$ & 32,023 &,- 940 & 1,090 \\
GOV & $?$ & $-5,225$ & 1,510 & $-3,461^{* * * *}$ & 1,188 \\
SIZE & + & 17,034 & 4,619 & $3,688^{* * * *}$ & 1,090 \\
SECT & + &,- 008 & 1,422 &,- 006 & 1,040 \\
ROA & + &, 010 &, 090 & 112 & 1,090 \\
Adjusted $\mathrm{R}^{2}(\%)$ &, 216 & & & & \\
F-value & 5,624 & & & & \\
Probability $>\mathrm{F}$ &, 001 & & & & \\
N & 68 & & & & \\
\hline
\end{tabular}

Variable definitions: CSR $=$ social performance index between $0 \%$ and 100\%; SIZE $=$ the natural logarithm of total assets; ROA = pre-tax income divided by total assets; GOV = a dummy variable that takes the value 1 when the family firm is managed by a family member CEO and 0 otherwise; SECT = a dummy variable that takes the value 1 when the family firm's activity sector is sensitive to the environment (energy, chemicals, mining, and construction) and 0 otherwise. $\mathrm{N}=68$ for all variables. * Significance at the .10 level; ** Significance at the .05 level; *** Significance at the .01 level.

Table 3 also shows that some of the regression coefficients for the control variables are significant. Indeed, SIZE is positive and significant $(\mathrm{p}<0,01)$ as expected. Due to their higher visibility, larger corporations provide more corporate social performance than smaller corporations. Finally, the regression coefficients for SECT and ROA are not significant.

\subsection{Robustness Checks}

We performed several robustness checks to evaluate the reliability of the OLS regression results presented in Table 3. First, we entered the control variables consecutively into the regression model and obtained similar results for GOV. Second, we dropped the control variables from the regression model, and our results for GOV were unchanged. Third, we computed variance inflation factors (VIFs) when estimating our regression model to test for signs of multi-collinearity between the explanatory variables. As no VIF exceeded five, we concluded that multicollinearity was not a major concern in our study (Hair et al., 2006). Overall, our OLS regression results are reliable.

\section{DISCUSSION}

Our findings show a negative and significant relationship between family involvement and corporate social performance. Thus, the higher the corporation's level of family involvement, the lower is the level of corporate social performance. CSR practices are then more developed in firms managed by a competent external CEO compared with those managed by a family member CEO. Our Hypothesis $\mathrm{H}_{2}$ is thus corroborated while Hypothesis $\mathrm{H}_{1}$ is rejected. We therefore confirm the conclusion of Morck and Yeung (2003), who state that a very strong degree of family control leads to a lower level of social responsibility.

Our results also show that French family firms increased their social performance during the 2005-2011 period. Thus, French family firms show a strategic interest in CSR, which can be seen as a driver of overall performance, which requires long-term commitment, and as an opportunity to better respond to the demands of the current economic context. Our results support the conclusions of Peloza (2006), who states that good social performance does not mean just benefits and profits, but can also be seen as a buffer to reduce the negative events that can result from downturns. Indeed, although the investment needed to establish and develop CSR practices is costly and generates expenses that will weigh on financial performance, French family firms are well aware that these expenses will be compensated by increased revenues through access to new markets sensitive to ethical considerations and strengthened employee productivity. 
Our findings also reveal a positive and significant relationship between company size and social performance. Thus, the bigger the firm, the bigger its CSR effort will be. This finding supports the conclusions of several authors who report that firm size positively influences social performance (Stanwick \& Stanwick, 1998; Johnson \& Greening, 1999).

Moreover, our results show a positive but not significant relationship between social and financial performance. It would nevertheless be interesting to study this relationship over the long term. Indeed, Preston and O'Bannon (1997) show that strong financial performance will push managers to moderately develop social performance in order to increase firm profitability and thereby increase their own revenues, while poor financial performance will prompt them to significantly develop social performance. Moreover, Mahoney and Robert (2007) and Makni et al. (2009) argue that in the short term, social performance negatively influences financial performance, but that in the long term this impact tends to become positive.

Last, we find no significant relationship between the activity sector and social performance. This result leads us to believe that listed companies face regulatory pressure, particularly through the NRE law, that shapes their managerial behavior toward greater responsibility and social commitment.

\section{CONCLUSION}

This paper examines the CSR practices of French family firms with respect to their degree of family involvement. The practices are assessed through five dimensions: ethics and sustainability, environmental management, responsible products, social conduct, and governance. We then conduct Pearson correlation analysis and ordinary least squares regression analysis to study the relationships between social performance and family involvement.

Our results allow us to state that the higher the firm's level of family involvement, the lower the level of corporate social performance. Thus, family firms managed by a competent external manager demonstrate better social performance than those managed by a family member CEO. This observation is most likely due to the healthy balance of power that external CEOs are able to establish in the firm. We also find that during the 2005-2011 period, French family firms developed their CSR practices. Indeed, these firms are well aware of the strategic interest of CSR with regard to their activity. Moreover, our results show a positive but not significant relationship between financial performance and social performance. Last, our results show no significant relationship between the activity sector and social performance, and they reveal a positive and significant relationship between firm size and social performance.

\section{AUTHOR INFORMATION}

Issam Laguir is an Assistant Professor of Accounting and Management Control at Groupe Sup de Co Montpellier Business School (France). His research focuses on social and environmental accounting, corporate governance and taxation. E-mail: i.laguir@ supco-montpellier.fr (Corresponding author)

Jamal Elbaz is an Assistant Professor of Supply Chain Management at Ibn Zohr University (Morocco). His research focuses on supply chain management and corporate governance. E-mail: elbaz j@ hotmail.com

\section{REFERENCES}

1. Anderson, J. C., \& Gerbing, D. W. (1988). Structural equation modeling in practice: A review and recommended two-step approach. Psychological Bulletin, 10(3), 411-423.

2. Adhikari, A., \& Tondkar, R. H. (1992). Environmental factors influencing accounting disclosure requirements of global stock exchanges. Journal of International Financial Management and Accounting, 4(2), 75-105.

3. Aronoff, C. E., \& Ward, J. L. (1995). Family-owned business: A thing of the past or a model for the future. Family Business Review, 8, 121-130. 
4. $\quad$ Anderson, R. C., \& Reeb, D. M. (2003). Founding-family ownership and firm performance: Evidence from the S\&P 500. Journal of Finance, 58, 1301-1328.

5. Bentler, P. M., \& Chou, C.-P. (1987). Practical issues in structural modeling. Sociological Methods \& Research, 16(1), 78-117.

6. Bowen, H. (1953). Social responsibilities of the business man. New York, NY: Harper and Brothers.

7. Capron, M., \& Quairel-Lanoizelée, F. (2007). La responsabilité sociale d'entreprise. Paris: la Découverte.

8. Capron, M., \& Quairel-Lanoizelée, F. (2004). Mythes et réalités de l'entreprise responsable. Paris: La Découverte.

9. Caroll, A. (1991). The pyramid of corporate social responsibility: Toward the moral management of organizational stakeholders. Business Horizons, 34(4), 39-48.

10. Caroll, A. (1979). A three-dimensional conceptual model of corporate social performance. Academy of Management Review, 4(4), 497-505.

11. Cho, C. H., \& Paton, D. M. (2007). The role of environmental disclosures as tools of legitimacy: A research note. Accounting, Organizations, and Society, 32(7-8), 639-647.

12. Chrisman, J. J., Chua, J. H., \& Sharma P. (2005). Trends and directions in the development of a strategic management theory of the family firm. Entrepreneurship Theory \& Practice, 29(5), 555-576.

13. Christensen, J. (2002). Bishop mines. Brigham Young University Case Study. Provo, UT: Brigham Young University.

14. Chua, J. H., Chrisman J. J., \& Sharma P. (1999). Defining the family business by behavior. Entrepreneurship Theory \& Practice, 23(4), 19-39.

15. Commission of the European Communities (2001). Green paper, promoting a European framework for corporate social responsibility. Brussels.

16. Corbetta, G., \& Salvato, C. (2004). Self-serving or self-actualizing? Models of man and agency costs in different types of family firms: A commentary on comparing the agency costs of family and non-family firms: Conceptual issues and exploratory evidence. Entrepreneurship Theory \& Practice, 28(4), 355-362.

17. Cormier, D., Gordon, I. M., \& Magnan, M. (2004). Corporate environmental disclosure: Contrasting management's perceptions with reality. Journal of Business Ethics, 49(2), 143-166.

18. Davis, J. H., Schoorman, F. D., \& Donaldson, L. (1997). Toward a stewardship theory of management. Academy of Management Review, 22, 20-47.

19. Dibrell, C., \& Moeller, M. (2011). The impact of a service-dominant focus strategy and stewardship culture on organizational innovativeness in family-owned businesses. Journal of Family Business Strategy, 2, 4351.

20. Dyer, W. G., Jr. (1986). Cultural change in family firms. San Francisco, CA: Jossey-Bass.

21. Dyer, W. G., \& Whetten, D. A. (2006). Family firms and social responsibility: Preliminary evidence from the S\&P 500. Entrepreneurship Theory \& Practice, 30(6), 785-802.

22. Freeman, R. (1984). Strategic management: a stakeholder approach. Londres: Pitman Publishing.

23. Gomez-Mejia, L. R., Nuñez-Nickel, M., \& Gutierrez, I. (2001). The role of family ties in agency contracts. Academy of Management Journal, 44(1), 81-95.

24. Gray, R., Dey, C., Owen, D., Evans, R., \& Zadek, S. (1997). Struggling with the praxis of social accounting: Stakeholders, accountability, audits and procedures. Accounting, Auditing \& Accountability Journal, 10(3), 325-64.

25. Hair, J. F., Black, W. C., Babin, B. J., Anderson, R. E., \& Tatham, R. L. (2006). Multivariate data analysis, (6th ed.). Upper Saddle River, NJ: Pearson Prentice-Hall.

26. Haniffa, R. M., \& Cooke, T. E. (2005). The impact of culture and governance on corporate social reporting. Journal of Accounting \& Public Policy, 24, 340-391.

27. Hogg, M. A. (2003). Social identity. In M. R. Leary \& J. P. Tangney (Eds.), Handbook of self \& identity (pp. 462-479). New York: Guilford Press.

28. Hogg, M. A., \& Terry, D. J. (2001). Social identity processes in organizational contexts. Philadelphia: Psychology Press.

29. Jackson, G., \& Apostolakou, A. (2010). Corporate social responsibility in western Europe: CSR as an institutional mirror or a substitute? Journal of Business Ethics, 94(3), 371-394.

30. Johnson, R. A., \& Greening, D. W. (1999). The effects of corporate governance and institutional ownership types of corporate social performance. Academy of Management Journal, 42(5), 564-576.

31. Kaye, K. (1991). Penetrating the cycle of sustained conflict. Family Business Review, 4(1), 21-44. 
32. Lanis, R., \& Richardson, G. (2012). Corporate social responsibility and tax aggressiveness: An empirical analysis. Journal of Accounting \& Public Policy, 31(1), 86-108.

33. Lansberg, I. (1999). Succeeding generations. Boston, MA: Harvard Business School Press.

34. Le Foll, A., \& De Pirey, E. (2004). Héritiers et managers. Revue Française de Comptabilité, 370, 41-48.

35. Magness, V. (2006). Strategic posture, financial performance and environmental disclosure: An empirical test of legitimacy theory. Accounting, Auditing \& Accountability Journal, 19(4), 540-63.

36. Mahoney, L. S., \& Roberts, R. W. (2007). Corporate social performance, financial performance and institutional ownership in Canadian firms. Accounting Forum, 31(3), 233-253.

37. Maignan, I., \& Ralston, D. A. (2002). Corporate social responsibility in Europe and the U.S.: Insights from businesses' self-presentations. Journal of International Business Studies, 33(3), 497-514.

38. Makni, R., Francoeur, C., \& Bellavance, F. (2009). Causality between corporate social performance and financial performance: Evidence from Canadian firms. Journal of Business Ethics, 89(3), 409-422.

39. Margolis, J. D., \& Walsh, J. P. (2003). Misery loves companies: Rethinking social initiatives by business. Administrative Science Quarterly, 48(2), 268 -305.

40. Matten, D., \& Moon, J. (2008). Implicit and explicit CSR: A conceptual framework for a comparative understanding of corporate social responsibility. Academy of Management Review, 33(2), 404-424.

41. Miller, D., \& Le Breton-Miller, I. (2003). Challenge versus advantage in family business. Strategic Organization, 1, 127-134.

42. Mishra, C. S., \& McConaughy D. L. (1999). Founding family control and capital structure: The risk of loss of control and the aversion to debt. Entrepreneurship Theory \& Practice, 23(4), 53-64.

43. Mittal, R. K., Sinha, N., \& Singh, A. (2008). An analysis of linkage between economic value added and corporate social responsibility. Management Decision, 46(9), 1437-1443.

44. Mitchell, R. K., Agle, B. R., \& Wood, D. J. (1997). Towards a theory of stakeholder identification and salience: Defining the principle of who and what really counts. Academy of Management Review, 22(4), 853-886.

45. Morck, R., \& Yeung, B. (2003). Agency problems in large family business groups. Entrepreneurship Theory \& Practice, 27(4), 367-382.

46. Morck, R., \& Yeung, B. (2004). Family control and the rent-seeking society. Entrepreneurship Theory \& Practice, 28(4), 391-409.

47. Orlitzky, M., Schmidt, F. L., \& Rynes, S. L. (2003). Corporate social and financial performance: A metaanalysis. Organization Studies, 24(3), 403-441.

48. O'Boyle, E. H. Jr., Rutherford, M. W., \& Pollack J. M. (2010). Examining the relation between ethical focus and financial performance in family firms: An exploratory study. Family Business Review, 23(4), 310-326.

49. Peloza, J. (2006). Using corporate social responsibility as insurance for financial performance. California Management Review, 48(2), 52-72.

50. Preston, L. E., \& O'Bannon, D. P. (1997). The corporate social-financial performance relationship: A typology and analysis. Business \& Society, 36(4), 419-429.

51. Roberts, R. W. (1992). Determinants of corporate social responsibility disclosure. Accounting, Organizations \& Society, 17(6), 595-612.

52. Rosenblatt, P. C., de Mik, L., Anderson, R. M., \& Johnson, P. A. (1985). The family in business. San Francisco, CA: Jossey-Bass.

53. Scholtens, B. (2009). Corporate social responsibility in the international banking industry. Journal of Business Ethics, 86, 159-175

54. Schulze, W. G., Lubatkin, M. H., \& Dino, R. N. (2003). Exploring the agency consequences of ownership dispersion among the directors of private family firms. Academy of Management Journal, 46(2), 179-194.

55. Schulze, W. G., Lubatkin, M. H., Dino, R. N., \& Buchholtz, A. K. (2001). Agency relationships in family firms: Theory and evidence. Organization Science, 12(2), 99-116.

56. Suchman, M. C. (1995). Managing legitimacy: Strategic and institutional approaches. Academy of Management Review, 20(3), 571-606.

57. Stanwick, S. D., \& Stanwick, P. A. (1998). The relation between corporate social performance and organizational size, financial performance, and environmental performance: An empirical examination. Journal of Business Ethics, 17(2), 195-204. 
58. Stray, S., \& Ballantine, J. (2000). A sectoral comparison of corporate environmental reporting and disclosure. Eco-Management \& Auditing, 7(4), 165-177.

59. Tilling, M. V., \& Tilt, C. A. (2010). The edge of legitimacy: Voluntary social and environmental reporting in Rothmans' 1956-1999 annual reports. Accounting, Auditing \& Accountability Journal, 23(1), 55-81.

60. Van Marrewijk, M. (2003). Concepts and definitions of CSR and corporate sustainability: Between agency and communion. Journal of Business Ethics, 44(2/3), 95-106.

61. Wallace, R. S. O. (1988). Intranational and international consensus on the importance of disclosure items in financial reports: A Nigerian case. British Accounting Review, 20, 223-265.

62. Wan, S. W. (2006). Defining corporate social responsibility. Journal of Public Affairs, 6, 176-184.

63. Ward, J. L. (1987). Keeping the family business healthy. San Francisco, CA: Jossey-Bass.

64. Wilmshurst, T. D., \& Frost, G. R. (2000). Corporate environmental reporting: A test of legitimacy theory. Accounting, Auditing \& Accountability Journal, 13(1), 10-26.

65. Wood, D. (1991). Corporate social performance revisited. Academy of Management Review, 16(4), 691718.

66. Zahra, S., Neubaum, D., Hayton, J., Dibrell, C., \& Craig, J. (2008). Culture of family commitment and strategic flexibility: The moderating effect of stewardship. Entrepreneurship: Theory \& Practice, 32, 10351054.

67. Zarzeski, M. T. (1996). Spontaneous harmonization effects of culture and market forces on accounting disclosure practices. Accounting Horizons, 10, 18-37. 


\section{APPENDICES}

Appendix A: CSR Indicators for French Family Firms

\begin{tabular}{|c|c|c|c|c|}
\hline Areas of CSR Actions & $\mathbf{N}^{\circ}$ & Indicators & Operationalization & $\begin{array}{l}\text { Source } \\
\end{array}$ \\
\hline \multirow{3}{*}{$\begin{array}{l}\text { Ethics and } \\
\text { Sustainability }\end{array}$} & 1 & Sustainability reports & Yes $(1)$ or No $(0)$ & Websites and firm reports \\
\hline & 2 & UN Global Compact & Adopted (Yes / No) & \\
\hline & 3 & $\begin{array}{l}\text { ICC Business Charter } \\
\text { Sustainable Development }\end{array}$ & Adopted (Yes / No) & $\begin{array}{l}\text { principles.com } \\
\text { www.unglobalcompact.org }\end{array}$ \\
\hline \multirow{7}{*}{$\begin{array}{l}\text { Environmental } \\
\text { Management }\end{array}$} & 4 & $\begin{array}{l}\text { Certified environmental } \\
\text { management system } \\
\text { (EMAS, ISO 14001) }\end{array}$ & Certified (Yes / No) & Websites and firm reports \\
\hline & 5 & Environmental policy & Adopted (Yes / No) & Websites and firm reports \\
\hline & 6 & Supply chain management & Sustainability policies (Yes / No) & Websites and firm reports \\
\hline & 7 & $\begin{array}{l}\text { Quantified environmental } \\
\text { management targets }\end{array}$ & Yes or No & Websites and firm reports \\
\hline & 8 & $\begin{array}{l}\text { Transparency of } \\
\text { environmental } \\
\text { performance }\end{array}$ & Quantitative ou qualitative & Websites and firm reports \\
\hline & 9 & $\begin{array}{l}\text { Environmental risk } \\
\text { management in lending } \\
\text { policy }\end{array}$ & Yes or No & Websites and firm reports \\
\hline & 10 & Eco-design & Yes or No & Websites and firm reports \\
\hline \multirow{3}{*}{ Responsible Products } & 11 & Product components & $\begin{array}{l}\text { Exclusion of toxic components to } \\
\text { manufacture products (Yes / No) }\end{array}$ & Websites and firm reports \\
\hline & 12 & Responsible consumption & $\begin{array}{l}\text { customer awareness of "green", } \\
\text { "ethical" or "fair" approaches (Yes / } \\
\text { No) }\end{array}$ & Websites and firm reports \\
\hline & 13 & Market partnership & $\begin{array}{l}\text { Partnership with competing or } \\
\text { complementary companies to create } \\
\text { a CSR market (Yes / No) }\end{array}$ & Websites and firm reports \\
\hline \multirow{6}{*}{ Social Conduct } & 14 & Sponsoring & $\begin{array}{l}\text { Sponsoring of community activities } \\
\text { and NGOs (Yes / No) }\end{array}$ & Websites and firm reports \\
\hline & 15 & Community involvement & $\begin{array}{l}\text { Donations and volunteering (Yes / } \\
\text { No) }\end{array}$ & Websites and firm reports \\
\hline & 16 & Training and education & Yes or No & Websites and firm reports \\
\hline & 17 & $\begin{array}{l}\text { Diversity and } \\
\text { opportunities }\end{array}$ & Yes or No & Websites and firm reports \\
\hline & 18 & Feedback from employees & Yes or No & Websites and firm reports \\
\hline & 19 & Business ethics & Code of Conduct (Yes / No) & Websites and firm reports \\
\hline \multirow{6}{*}{ Governance } & 20 & $\begin{array}{l}\text { Commitment of leadership } \\
\text { to CSR }\end{array}$ & Yes or No & Websites and firm reports \\
\hline & 21 & $\begin{array}{l}\text { Measurement of the } \\
\text { improvements in actions }\end{array}$ & Yes or No & Websites and firm reports \\
\hline & 22 & $\begin{array}{l}\text { Implementation/use of } \\
\text { standards }\end{array}$ & Yes or No & Websites and firm reports \\
\hline & 23 & $\begin{array}{l}\text { External evaluation of the } \\
\text { CSR policy }\end{array}$ & Yes or No & Websites and firm reports \\
\hline & 24 & $\begin{array}{l}\text { Internal evaluation of the } \\
\text { CSR policy }\end{array}$ & Yes or No & Websites and firm reports \\
\hline & 25 & $\begin{array}{l}\text { Involvement of } \\
\text { stakeholders in corporate } \\
\text { governance }\end{array}$ & Yes or No & Websites and firm reports \\
\hline
\end{tabular}


Appendix B: Social Performance of French Family Firms during the 2005-2011 Period

\begin{tabular}{|c|c|c|c|c|c|c|c|c|c|c|c|c|c|c|c|c|c|c|c|c|}
\hline \multirow{3}{*}{ CSR } & \multicolumn{20}{|c|}{ Family Firms Managed by a Family Member CEO (Category A) } \\
\hline & \multicolumn{8}{|c|}{ LVMH } & \multicolumn{8}{|c|}{ Cap Gemini } & \multicolumn{4}{|c|}{$\begin{array}{l}\text { Peugeot SA } \\
\end{array}$} \\
\hline & 05 & 06 & 07 & 08 & 09 & 10 & 11 & 12 & 05 & 06 & 07 & 08 & 09 & 10 & 11 & 12 & 05 & 06 & 07 & 08 \\
\hline 1 & 1 & 1 & 1 & 1 & 1 & 1 & 1 & 1 & 0 & 0 & 0 & 0 & 0 & 1 & 1 & 1 & 0 & 0 & 0 & 0 \\
\hline 2 & 1 & 1 & 1 & 1 & 1 & 1 & 1 & 1 & 1 & 1 & 1 & 1 & 1 & 1 & 1 & 1 & 1 & 1 & 1 & 1 \\
\hline 3 & 0 & 0 & 0 & 0 & 0 & 0 & 0 & 0 & 0 & 0 & 0 & 0 & 0 & 0 & 0 & 0 & 0 & 0 & 0 & 0 \\
\hline 4 & 1 & 1 & 1 & 1 & 1 & 1 & 1 & 1 & 0 & 0 & 0 & 0 & 0 & 1 & 1 & 1 & 1 & 1 & 1 & 1 \\
\hline 5 & 1 & 1 & 1 & 1 & 1 & 1 & 1 & 1 & 1 & 1 & 1 & 1 & 1 & 1 & 1 & 1 & 1 & 1 & 1 & 1 \\
\hline 6 & 1 & 1 & 1 & 1 & 1 & 1 & 1 & 1 & 1 & 1 & 1 & 1 & 1 & 1 & 1 & 1 & 1 & 1 & 1 & 1 \\
\hline 7 & 1 & 1 & 1 & 1 & 1 & 1 & 1 & 1 & 0 & 0 & 0 & 1 & 1 & 1 & 1 & 1 & 1 & 1 & 1 & 1 \\
\hline 8 & 1 & 1 & 1 & 1 & 1 & 1 & 1 & 1 & 1 & 1 & 1 & 1 & 1 & 1 & 1 & 1 & 1 & 1 & 1 & 1 \\
\hline 9 & 1 & 1 & 1 & 1 & 1 & 1 & 1 & 1 & 1 & 1 & 1 & 1 & 1 & 1 & 1 & 1 & 1 & 1 & 1 & 1 \\
\hline 10 & 1 & 1 & 1 & 1 & 1 & 1 & 1 & 1 & 1 & 1 & 1 & 1 & 1 & 1 & 1 & 1 & 1 & 1 & 1 & 1 \\
\hline 11 & 0 & 1 & 1 & 1 & 1 & 1 & 1 & 1 & 0 & 0 & 0 & 0 & 0 & 0 & 0 & 0 & 1 & 1 & 1 & 1 \\
\hline 12 & 1 & 1 & 1 & 1 & 1 & 1 & 1 & 1 & 1 & 1 & 1 & 1 & 1 & 1 & 1 & 1 & 1 & 1 & 1 & 1 \\
\hline 13 & 0 & 0 & 0 & 0 & 0 & 0 & 0 & 0 & 0 & 0 & 0 & 0 & 0 & 0 & 0 & 0 & 0 & 0 & 0 & 0 \\
\hline 14 & 1 & 1 & 1 & 1 & 1 & 1 & 1 & 1 & 1 & 1 & 1 & 1 & 1 & 1 & 1 & 1 & 1 & 1 & 1 & 1 \\
\hline 15 & 1 & 1 & 1 & 1 & 1 & 1 & 1 & 1 & 1 & 1 & 1 & 1 & 1 & 1 & 1 & 1 & 1 & 1 & 1 & 1 \\
\hline 16 & 1 & 1 & 1 & 1 & 1 & 1 & 1 & 1 & 1 & 1 & 1 & 1 & 1 & 1 & 1 & 1 & 1 & 1 & 1 & 1 \\
\hline 17 & 1 & 1 & 1 & 1 & 1 & 1 & 1 & 1 & 1 & 1 & 1 & 1 & 1 & 1 & 1 & 1 & 1 & 1 & 1 & 1 \\
\hline 18 & 0 & 1 & 1 & 1 & 1 & 1 & 1 & 1 & 1 & 1 & 1 & 1 & 1 & 1 & 1 & 1 & 1 & 1 & 1 & 1 \\
\hline 19 & 1 & 1 & 1 & 1 & 1 & 1 & 1 & 1 & 1 & 1 & 1 & 1 & 1 & 1 & 1 & 1 & 1 & 1 & 1 & 1 \\
\hline 20 & 1 & 1 & 1 & 1 & 1 & 1 & 1 & 1 & 1 & 1 & 1 & 1 & 1 & 1 & 1 & 1 & 1 & 1 & 1 & 1 \\
\hline 21 & 1 & 1 & 1 & 1 & 1 & 1 & 1 & 1 & 1 & 1 & 1 & 1 & 1 & 1 & 1 & 1 & 1 & 1 & 1 & 1 \\
\hline 22 & 1 & 1 & 1 & 1 & 1 & 1 & $\begin{array}{l}1 \\
1\end{array}$ & $\begin{array}{l}1 \\
1\end{array}$ & 1 & 1 & 1 & 1 & 1 & 1 & 1 & 1 & 1 & 1 & 1 & 1 \\
\hline 23 & 1 & 1 & 1 & 1 & 1 & 1 & 1 & 1 & 0 & 0 & 0 & 0 & 0 & 1 & 1 & 1 & 0 & 0 & 0 & 0 \\
\hline 24 & 1 & 1 & 1 & 1 & 1 & 1 & 1 & 1 & 1 & 1 & 1 & 1 & 1 & 1 & 1 & 1 & 1 & 1 & 1 & 1 \\
\hline 25 & 1 & 1 & 1 & 1 & 1 & 1 & 1 & 1 & 1 & 1 & 1 & 1 & 1 & 1 & 1 & 1 & 1 & 1 & 1 & 1 \\
\hline $\mathbf{T}$ & 84 & 92 & 92 & 92 & 92 & 92 & 92 & 92 & 72 & 72 & 72 & 76 & 76 & 88 & 88 & 88 & 84 & 84 & 84 & 84 \\
\hline
\end{tabular}

\begin{tabular}{|c|c|c|c|c|c|c|c|c|c|c|c|c|c|c|c|c|c|c|c|c|}
\hline \multirow{3}{*}{ CSR } & \multicolumn{20}{|c|}{ Family Firms Managed by a Family Member CEO (Category A) } \\
\hline & \multicolumn{4}{|c|}{ Peugeot SA } & \multicolumn{8}{|c|}{ Bouygues } & \multicolumn{8}{|c|}{ PPR } \\
\hline & 09 & 10 & 11 & 12 & 05 & 06 & $\mathbf{0 7}$ & 08 & 09 & $\mathbf{1 0}$ & 11 & 12 & 05 & 06 & $\mathbf{0 7}$ & 08 & 09 & $\mathbf{1 0}$ & 11 & 12 \\
\hline 1 & 0 & 1 & 1 & 1 & 0 & 0 & 0 & 0 & 1 & 1 & 1 & 1 & 0 & 0 & 0 & 1 & 1 & 1 & 1 & 1 \\
\hline 2 & 1 & 1 & 1 & 1 & 1 & 1 & 1 & 1 & 1 & 1 & 1 & 1 & 0 & 0 & 0 & 1 & 1 & 1 & 1 & 1 \\
\hline 3 & 0 & 0 & 0 & 0 & 0 & 0 & 0 & 0 & 0 & 0 & 0 & 0 & 0 & 0 & 0 & 0 & 0 & 0 & 0 & 0 \\
\hline 4 & 1 & 1 & 1 & 1 & 1 & 1 & 1 & 1 & 1 & 1 & 1 & 1 & 1 & 1 & 1 & 1 & 1 & 1 & 1 & 1 \\
\hline 5 & 1 & 1 & 1 & 1 & 1 & 1 & 1 & 1 & 1 & 1 & 1 & 1 & 1 & 1 & 1 & 1 & 1 & 1 & 1 & 1 \\
\hline 6 & 1 & 1 & 1 & 1 & 1 & 1 & 1 & 1 & 1 & 1 & 1 & 1 & 1 & 1 & 1 & 1 & 1 & 1 & 1 & 1 \\
\hline 7 & 1 & 1 & 1 & 1 & 0 & 0 & 1 & 1 & 1 & 1 & 1 & 1 & 0 & 1 & 1 & 1 & 1 & 1 & 1 & 1 \\
\hline 8 & 1 & 1 & 1 & 1 & 1 & 1 & 1 & 1 & 1 & 1 & 1 & 1 & 1 & 1 & 1 & 1 & 1 & 1 & 1 & 1 \\
\hline 9 & 1 & 1 & 1 & 1 & 1 & 1 & 1 & 1 & 1 & 1 & 1 & 1 & 1 & 1 & 1 & 1 & 1 & 1 & 1 & 1 \\
\hline 10 & 1 & 1 & 1 & 1 & 1 & 1 & 1 & 1 & 1 & 1 & 1 & 1 & 1 & 1 & 1 & 1 & 1 & 1 & 1 & 1 \\
\hline 11 & 1 & 1 & 1 & 1 & 0 & 0 & 0 & 0 & 0 & 0 & 0 & 0 & 1 & 1 & 1 & 1 & 1 & 1 & 1 & 1 \\
\hline 12 & 1 & 1 & 1 & 1 & 1 & 1 & 1 & 1 & 1 & 1 & 1 & 1 & 1 & 1 & 1 & 1 & 1 & 1 & 1 & 1 \\
\hline 13 & 0 & 0 & 0 & 0 & 0 & 0 & 0 & 0 & 0 & 0 & 0 & 0 & 0 & 0 & 0 & 0 & 0 & 0 & 0 & 0 \\
\hline 14 & 1 & 1 & 1 & 1 & 1 & 1 & 1 & 1 & 1 & 1 & 1 & 1 & 1 & 1 & 1 & 1 & 1 & 1 & 1 & 1 \\
\hline 15 & 1 & 1 & 1 & 1 & 1 & 1 & 1 & 1 & 1 & 1 & 1 & 1 & 1 & 1 & 1 & 1 & 1 & 1 & 1 & 1 \\
\hline 16 & 1 & 1 & 1 & 1 & 1 & 1 & 1 & 1 & 1 & 1 & 1 & 1 & 1 & 1 & 1 & 1 & 1 & 1 & 1 & 1 \\
\hline 17 & 1 & 1 & 1 & 1 & 1 & 1 & 1 & 1 & 1 & 1 & 1 & 1 & 1 & 1 & 1 & 1 & 1 & 1 & 1 & 1 \\
\hline 18 & 1 & 1 & 1 & 1 & 1 & 1 & 1 & 1 & 1 & 1 & 1 & 1 & 1 & 1 & 1 & 1 & 1 & 1 & 1 & 1 \\
\hline 19 & 1 & 1 & 1 & 1 & 1 & 1 & 1 & 1 & 1 & 1 & 1 & 1 & 1 & 1 & 1 & 1 & 1 & 1 & 1 & 1 \\
\hline 20 & 1 & 1 & 1 & 1 & 1 & 1 & 1 & 1 & 1 & 1 & 1 & 1 & 1 & 1 & 1 & 1 & 1 & 1 & 1 & 1 \\
\hline 21 & 1 & 1 & 1 & 1 & 1 & 1 & 1 & 1 & 1 & 1 & 1 & 1 & 1 & 1 & 1 & 1 & 1 & 1 & 1 & 1 \\
\hline 22 & 1 & 1 & 1 & 1 & 1 & 1 & 1 & 1 & 1 & 1 & 1 & 1 & 1 & 1 & 1 & 1 & 1 & 1 & 1 & 1 \\
\hline 23 & 0 & 1 & 1 & 1 & 0 & 0 & 0 & 0 & 0 & 1 & 1 & 1 & 1 & 1 & 1 & 1 & 1 & 1 & 1 & 1 \\
\hline 24 & 1 & 1 & 1 & 1 & 1 & 1 & 1 & 1 & 1 & 1 & 1 & 1 & 1 & 1 & 1 & 1 & 1 & 1 & 1 & 1 \\
\hline 25 & 1 & 1 & 1 & 1 & 1 & 1 & 1 & 1 & 1 & 1 & 1 & 1 & 1 & 1 & 1 & 1 & 1 & 1 & 1 & 1 \\
\hline $\mathbf{T}$ & 84 & 92 & 92 & 92 & 76 & 76 & 80 & 80 & 84 & 88 & 88 & 88 & 80 & 84 & 84 & 92 & 92 & 92 & 92 & 92 \\
\hline
\end{tabular}




\begin{tabular}{|c|c|c|c|c|c|c|c|}
\hline \multirow{3}{*}{ CSR } & \multicolumn{7}{|c|}{ Family Firms Managed by a Family Member CEO (Category A) } \\
\hline & \multicolumn{7}{|c|}{ Pernaud Ricard } \\
\hline & 05 & 06 & 07 & 08 & 09 & 10 & 11 \\
\hline 1 & 0 & 0 & 0 & 0 & 0 & 0 & 0 \\
\hline 2 & 1 & 1 & 1 & 1 & 1 & 1 & 1 \\
\hline 3 & 0 & 0 & 0 & 0 & 0 & 0 & 0 \\
\hline 4 & 1 & 1 & 1 & 1 & 1 & 1 & 1 \\
\hline 5 & 1 & 1 & 1 & 1 & 1 & 1 & 1 \\
\hline 6 & 1 & 1 & 1 & 1 & 1 & 1 & 1 \\
\hline 7 & 0 & 1 & 1 & 1 & 1 & 1 & 1 \\
\hline 8 & 1 & 1 & 1 & 1 & 1 & 1 & 1 \\
\hline 9 & 1 & 1 & 1 & 1 & 1 & 1 & 1 \\
\hline 10 & 1 & 1 & 1 & 1 & 1 & 1 & 1 \\
\hline 11 & 0 & 0 & 0 & 0 & 0 & 0 & 0 \\
\hline 12 & 1 & 1 & 1 & 1 & 1 & 1 & 1 \\
\hline 13 & 0 & 0 & 0 & 0 & 0 & 0 & 0 \\
\hline 14 & 1 & 1 & 1 & 1 & 1 & 1 & 1 \\
\hline 15 & 1 & 1 & 1 & 1 & 1 & 1 & 1 \\
\hline 16 & 1 & 1 & 1 & 1 & 1 & 1 & 1 \\
\hline 17 & 1 & 1 & 1 & 1 & 1 & 1 & 1 \\
\hline 18 & 1 & 1 & 1 & 1 & 1 & 1 & 1 \\
\hline 19 & 1 & 1 & 1 & 1 & 1 & 1 & 1 \\
\hline 20 & 1 & 1 & 1 & 1 & 1 & 1 & 1 \\
\hline 21 & 1 & 1 & 1 & 1 & 1 & 1 & 1 \\
\hline 22 & 1 & 1 & 1 & 1 & 1 & 1 & 1 \\
\hline 23 & 1 & 1 & 1 & 1 & 1 & 1 & 1 \\
\hline 24 & 1 & 1 & 1 & 1 & 1 & 1 & 1 \\
\hline 25 & 1 & 1 & 1 & 1 & 1 & 1 & 1 \\
\hline $\mathbf{T}$ & 80 & 84 & 84 & 84 & 84 & 84 & 84 \\
\hline
\end{tabular}

\begin{tabular}{|c|c|c|c|c|c|c|c|c|c|c|c|c|c|c|c|c|c|c|}
\hline \multirow{3}{*}{ CSR } & \multicolumn{18}{|c|}{ Family Firms Managed by a Competent External CEO $($ Category $B)$} \\
\hline & \multicolumn{6}{|c|}{ L'Oréal } & \multicolumn{9}{|c|}{ Michelin } & \multicolumn{3}{|c|}{ Alstom } \\
\hline & 05 & 06 & 07 & $\mathbf{0 8}$ & 09 & 10 & 11 & 05 & 06 & 07 & $\mathbf{0 8}$ & 09 & 10 & 11 & 05 & 06 & $\mathbf{0 7}$ & 08 \\
\hline 1 & 1 & 1 & 1 & 1 & 1 & 1 & 1 & 1 & 1 & 1 & 1 & 1 & 1 & 1 & 0 & 1 & 1 & 1 \\
\hline 2 & 1 & 1 & 1 & 1 & 1 & 1 & 1 & 0 & 0 & 0 & 0 & 0 & 1 & 1 & 0 & 1 & 1 & 1 \\
\hline 3 & 0 & 0 & 0 & 0 & 0 & 0 & 0 & 0 & 0 & 0 & 0 & 0 & 0 & 0 & 0 & 0 & 0 & 0 \\
\hline 4 & 1 & 1 & 1 & 1 & 1 & 1 & 1 & 1 & 1 & 1 & 1 & 1 & 1 & 1 & 1 & 1 & 1 & 1 \\
\hline 5 & 1 & 1 & 1 & 1 & 1 & 1 & 1 & 1 & 1 & 1 & 1 & 1 & 1 & 1 & 1 & 1 & 1 & 1 \\
\hline 6 & 1 & 1 & 1 & 1 & 1 & 1 & 1 & 1 & 1 & 1 & 1 & 1 & 1 & 1 & 1 & 1 & 1 & 1 \\
\hline 7 & 1 & 1 & 1 & 1 & 1 & 1 & 1 & 1 & 1 & 1 & 1 & 1 & 1 & 1 & 1 & 1 & 1 & 1 \\
\hline 8 & 1 & 1 & 1 & 1 & 1 & 1 & 1 & 1 & 1 & 1 & 1 & 1 & 1 & 1 & 1 & 1 & 1 & 1 \\
\hline 9 & 1 & 1 & 1 & 1 & 1 & 1 & 1 & 1 & 1 & 1 & 1 & 1 & 1 & 1 & 1 & 1 & 1 & 1 \\
\hline 10 & 1 & 1 & 1 & 1 & 1 & 1 & 1 & 1 & 1 & 1 & 1 & 1 & 1 & 1 & 1 & 1 & 1 & 1 \\
\hline 11 & 0 & 1 & 1 & 1 & 1 & 1 & 1 & 1 & 1 & 1 & 1 & 1 & 1 & 1 & 1 & 1 & 1 & 1 \\
\hline 12 & 1 & 1 & 1 & 1 & 1 & 1 & 1 & 1 & 1 & 1 & 1 & 1 & 1 & 1 & 1 & 1 & 1 & 1 \\
\hline 13 & 0 & 0 & 0 & 0 & 0 & 0 & 0 & 0 & 0 & 0 & 0 & 0 & 0 & 0 & 0 & 0 & 0 & 0 \\
\hline 14 & 1 & 1 & 1 & 1 & 1 & 1 & 1 & 1 & 1 & 1 & 1 & 1 & 1 & 1 & 1 & 1 & 1 & 1 \\
\hline 15 & 1 & 1 & 1 & 1 & 1 & 1 & 1 & 1 & 1 & 1 & 1 & 1 & 1 & 1 & 1 & 1 & 1 & 1 \\
\hline 16 & 1 & 1 & 1 & 1 & 1 & 1 & 1 & 1 & 1 & 1 & 1 & 1 & 1 & 1 & 1 & 1 & 1 & 1 \\
\hline 17 & 1 & 1 & 1 & 1 & 1 & 1 & 1 & 1 & 1 & 1 & 1 & 1 & 1 & 1 & 1 & 1 & 1 & 1 \\
\hline 18 & 1 & 1 & 1 & 1 & 1 & 1 & 1 & 1 & 1 & 1 & 1 & 1 & 1 & 1 & 1 & 1 & 1 & 1 \\
\hline 19 & 1 & 1 & 1 & 1 & 1 & 1 & 1 & 1 & 1 & 1 & 1 & 1 & 1 & 1 & 1 & 1 & 1 & 1 \\
\hline 20 & 1 & 1 & 1 & 1 & 1 & 1 & 1 & 1 & 1 & 1 & 1 & 1 & 1 & 1 & 1 & 1 & 1 & 1 \\
\hline 21 & 1 & 1 & 1 & 1 & 1 & 1 & 1 & 1 & 1 & 1 & 1 & 1 & 1 & 1 & 1 & 1 & 1 & 1 \\
\hline 22 & 1 & 1 & 1 & 1 & 1 & 1 & 1 & 1 & 1 & 1 & 1 & 1 & 1 & 1 & 1 & 1 & 1 & 1 \\
\hline 23 & 1 & 1 & 1 & 1 & 1 & 1 & 1 & 1 & 1 & 1 & 1 & 1 & 1 & 1 & 1 & 1 & 1 & 1 \\
\hline 24 & 1 & 1 & 1 & 1 & 1 & 1 & 1 & 1 & 1 & 1 & 1 & 1 & 1 & 1 & 1 & 1 & 1 & 1 \\
\hline 25 & 1 & 1 & 1 & 1 & 1 & 1 & 1 & 1 & 1 & 1 & 1 & 1 & 1 & 1 & 1 & 1 & 1 & 1 \\
\hline $\mathbf{T}$ & 88 & 92 & 92 & 92 & 92 & 92 & 92 & 88 & 88 & 88 & 88 & 88 & 92 & 92 & 84 & 92 & 92 & 92 \\
\hline
\end{tabular}




\begin{tabular}{l|cccccccccc}
\hline \multirow{3}{*}{ CSR } & \multicolumn{7}{|c}{ Family Firms Managed by $\boldsymbol{c}$ Competent External CEO (Category B) } \\
\cline { 2 - 11 } & $\mathbf{0 9}$ & $\mathbf{1 0}$ & $\mathbf{1 1}$ & $\mathbf{0 5}$ & $\mathbf{0 6}$ & $\mathbf{0 7}$ & $\mathbf{0 8}$ & $\mathbf{0 9}$ & $\mathbf{1 0}$ & $\mathbf{1 1}$ \\
\hline 1 & 1 & 1 & 1 & 0 & 0 & 0 & 0 & 1 & 1 & 1 \\
2 & 1 & 1 & 1 & 1 & 1 & 1 & 1 & 1 & 1 & 1 \\
3 & 0 & 0 & 0 & 0 & 0 & 0 & 0 & 0 & 0 & 0 \\
4 & 1 & 1 & 1 & 0 & 0 & 0 & 0 & 1 & 1 & 1 \\
5 & 1 & 1 & 1 & 1 & 1 & 1 & 1 & 1 & 1 & 1 \\
6 & 1 & 1 & 1 & 1 & 1 & 1 & 1 & 1 & 1 & 1 \\
7 & 1 & 1 & 1 & 0 & 0 & 0 & 0 & 1 & 1 & 1 \\
8 & 1 & 1 & 1 & 0 & 0 & 0 & 0 & 1 & 1 & 1 \\
9 & 1 & 1 & 1 & 1 & 1 & 1 & 1 & 1 & 1 & 1 \\
10 & 1 & 1 & 1 & 1 & 1 & 1 & 1 & 1 & 1 & 1 \\
11 & 1 & 1 & 1 & 1 & 1 & 1 & 1 & 1 & 1 & 1 \\
12 & 1 & 1 & 1 & 1 & 1 & 1 & 1 & 1 & 1 & 1 \\
13 & 0 & 0 & 0 & 0 & 0 & 0 & 0 & 0 & 0 & 0 \\
14 & 1 & 1 & 1 & 1 & 1 & 1 & 1 & 1 & 1 & 1 \\
15 & 1 & 1 & 1 & 1 & 1 & 1 & 1 & 1 & 1 & 1 \\
16 & 1 & 1 & 1 & 1 & 1 & 1 & 1 & 1 & 1 & 1 \\
17 & 1 & 1 & 1 & 1 & 1 & 1 & 1 & 1 & 1 & 1 \\
18 & 1 & 1 & 1 & 1 & 1 & 1 & 1 & 1 & 1 & 1 \\
19 & 1 & 1 & 1 & 1 & 1 & 1 & 1 & 1 & 1 & 1 \\
20 & 1 & 1 & 1 & 1 & 1 & 1 & 1 & 1 & 1 & 1 \\
21 & 1 & 1 & 1 & 1 & 1 & 1 & 1 & 1 & 1 & 1 \\
22 & 1 & 1 & 1 & 1 & 1 & 1 & 1 & 1 & 1 & 1 \\
23 & 1 & 1 & 1 & 1 & 1 & 1 & 1 & 1 & 1 & 1 \\
24 & 1 & 1 & 1 & 1 & 1 & 1 & 1 & 1 & 1 & 1 \\
25 & 1 & 1 & 1 & 1 & 1 & 1 & 1 & 1 & 1 & 1 \\
$\mathbf{T}$ & $\mathbf{9 2}$ & $\mathbf{9 2}$ & $\mathbf{9 2}$ & $\mathbf{7 6}$ & $\mathbf{7 6}$ & $\mathbf{7 6}$ & $\mathbf{7 6}$ & $\mathbf{9 2}$ & $\mathbf{9 2}$ & $\mathbf{9 2}$ \\
\hline & & & & & & & & & &
\end{tabular}




\section{NOTES}

